\title{
Development and characterization of microsatellite loci of Microglanis cottoides (Siluriformes: Pseudopimelodidae) and cross-species amplification
}

\author{
Lenice Souza-Shibatta ${ }^{1}$, Dhiego Gomes Ferreira ${ }^{2}$, Claudio Oliveira ${ }^{3}$, \\ Fernanda Simões de Almeida ${ }^{2}$, Oscar Akio Shibatta ${ }^{1}$ and Silvia Helena Sofia ${ }^{1,2}$
}

Thirteen microsatellite loci were isolated and characterized in Microglanis cottoides. Of these, two were monomorphic and 11 were polymorphic. These polymorphic loci tested on 24 individuals from a wild population produced a total of 108 different alleles, with levels of variability high, ranging from 2 to 20, with an average of 8.3 alleles per locus. The observed and expected heterozygosity ranged from 0.125 to 0.958 and from 0.119 to 0.931 , respectively. A high combined probability of paternity exclusion value and a low probability combined genetic identity value obtained show that the set of loci described herein displays good suitability for paternity studies and differentiation of $M$. cottoides. Additionally, all thirteen microsatellite primers developed for M. cottoides were tested in four other Pseudopimelodidae species and successful cross-species amplification was achieved for the majority of loci.

Treze loci microssatélites foram isolados e caracterizados em Microglanis cottoides. Destes, dois foram monomórficos e 11 foram polimórficos. Estes loci polimórficos foram testados em 24 indivíduos de uma população selvagem e produziram um total de 108 alelos diferentes, com níveis de variabilidade alta, variando de 2 a 20, com uma média de 8,3 alelos por locus. A heterozigosidade observada e esperada variou de 0,125 a 0,958 e 0,119 a 0,931 , respectivamente. Um elevado valor de exclusão de paternidade e um baixo valor de identidade genética foram obtidos, demostrando que o conjunto de loci descritos no presente trabalho exibe boa aplicabilidade no estudo de parentesco e diferenciação populacional em M. cottoides. Adicionalmente, os treze primers de microssatélites desenvolvidos para $M$. cottoides foram testados em outras quatro espécies de Pseudopimelodidae e a transferabilidade foi obtida para a maioria dos loci.

Key words: Brazilian Eastern basin, Catfish, Enriched genomic library, Genetic marker, SSR.

\section{Introduction}

Microglanis Eigenmann 1912, also known as bumblebee catfishes (Shibatta, 2003a), is a genus of small South American catfishes that do not exceed over $110 \mathrm{~mm}$ in standard length (Shibatta, 2003a; Shibatta \& Benine, 2005). Initially regarded as a member of the pimelodids (Eigenmann, 1912), this genus was subsequently included in the small Pseudopimelodidae family (Shibatta, 2003b), which is considered a monophyletic group (Lundberg et al., 1991).

With 21 valid species described to date (Ruiz \& Shibatta, 2011), the genus Microglanis is also characterized by its wide mouth (gape width same as head width), short maxillary barbel (occasionally reaching pectoral-fin origin) and small eye without free orbital margin, among other particular characters (Shibatta, 2003a, 2003b). These small catfishes are widely distributed across South America, occurring from Guyana to the Rio de La Plata basin in Argentina (Shibatta \& Benine, 2005; Sarmento-Soares et al., 2006).

Although our knowledge of the number of Microglanis species has increased in the last decade (Shibatta, 2003a, 2003b; Bertaco \& Cardoso, 2005; Shibatta \& Benine, 2005; Sarmento-Soares et al., 2006; Alcaraz et al., 2008; Ottoni et al., 2010; Shibatta \& Ruiz, 2010; Shibatta \& Ruiz, 2011), the

${ }^{1}$ Universidade Estadual de Londrina, Programa de Pós-Graduação em Ciências Biológicas, Departamento de Biologia Animal e Vegetal, Centro de Ciências Biológicas, 86051-990 Londrina, PR, Brazil. lenicesouza@hotmail.com (LSS); shibatta@uel.br(OAS)

${ }^{2}$ Universidade Estadual de Londrina, Programa de Pós-Graduação em Genética e Biologia Molecular, Departamento de Biologia Geral, Centro de Ciências Biológicas, 86051-990 Londrina, PR, Brazil. shsofia@uel.br (SHS)

${ }^{3}$ Universidade Paulista Júlio Mesquita Filho, Instituto de Biociências, Departamento de Biociências. Distrito de Rubião Júnior s/n, 18618970 Botucatu, SP, Brazil. 
biology of Microglanis still remains poorly known (Shibatta, 2003a). Recently, it has been shown that some species can occur in small populations patchily distributed along the river basins where they are found (Esguícero \& Arcifa, 2010). According to these authors, such conditions which may be associated with the progressive environmental degradation of freshwater habitats could represent threats to populations of some Microglanis species. Despite this fact, up to this moment population genetic studies involving Microglanis species are still lacking.

Among the known species, Microglanis cottoides (Boulenger 1891) is especially interesting for phylogeographic and genetic population studies, owing to its geographical distribution in the Brazilian Atlantic Forest, being present in the Uruguay River basin and along the eastern coast of Brazil, with records of their occurrence in drainages across the southern and southeastern regions (Malabarba \& Mahler, 1998; Shibatta, 2003b, 2007; Mori \& Shibatta, 2006). These regions can be considered of great biogeographical significance, not only for the high degree of endemism of its fish fauna (Bizerril, 1994, 1995), but also for being a very populated area with high environmental degradation due to human activities.

Studies on geographic distribution of genealogical lineages have been widely used to describe historical events, such as habitat fragmentation or expansion of the range of species and populations. These studies also serve to understand migration events, vicariance and extinction of gene lineages, and other processes that affect the population structure or generate speciation in a spatial and temporal context (Avise, 2001, 2009; Hardy et al., 2002).

A good way to study the genetic structure of natural fish populations is through the use of molecular markers such as microsatellite (SSR-Simple Sequence Repeats) (O'Connell \& Wright, 1997). In fact, SSR are considered a class of molecular markers highly polymorphic and useful for population studies (Zane et al., 2002). Therefore, the current work describes 13 SSR markers developed for Microglanis cottoides and tests their applicability for four other Pseudopimelodidae species.

\section{Material and Methods}

Microsatellites were isolated and characterized following the protocol of Billotte et al. (1999), with some minor modifications. Total genomic DNA was extracted from muscle tissue preserved in $95 \%$ ethanol. The DNA was isolated according to Almeida et al. (2001). Genomic DNA $(5 \mu \mathrm{g})$ was digested with $R s a \mathrm{I}$ and the blunt-ended fragments were ligated to the adaptors Rsa 21 and Rsa 25 (Edwards et al., 1996). Fragments were selected with (AGA) $5,(\mathrm{CT})_{8}$ and $(\mathrm{GT})_{8}$ probes, and then cloned into the pGem ${ }^{\circledR}-\mathrm{T}$ (Promega) vector. Such recombinant plasmids were used to transform the $E$. coli DH5- $\alpha$ lineage. The recombinant clones were selected and sequenced using the BigDye Terminator ${ }^{\mathrm{TM}}$ kit (v. 3.1 Applied Biosystems). Sequencing was performed on an ABI
$3500 \mathrm{XL}$ automated sequencer. Sequences were analyzed using BioEdit v.7.0 software (Hall, 1999) and primers were designed using Primer 3 software (Rozen \& Skaletsky, 2000). The selected forward primers were labelled with the M13 sequence (5'-TGTAAAACGACGGCCAGT-3') at the 5' end (Schuelke, 2000). The AutoDimer software (Vallone \& Butler, 2004) was used to test the potential presence of hairpin structures and primer-dimer problems. The individual genotyping was performed on an ABI $3500 \mathrm{XL}$ automated sequencer.

PCR amplifications were carried out on 24 individuals of $M$. cottoides (MZUEL 7453), collected in the arroio Divisa (30 $\left.54^{\circ} 5.6^{\prime \prime} \mathrm{S} 52^{\circ} 05^{\prime} 18.0^{\prime \prime} \mathrm{W}\right)$, municipality of Cristal, Rio Grande do Sul State, southern Brazil. Cross-species amplification tests were performed using four other pseudopimelodid species, as follows: Microglanis cibelae Malabarba \& Mahler, 1998 (MZUEL 7452), from the rio Maquiné (Rio Grande do Sul State, 29³7'2.1'S 50¹5'51.8'W); M. garavelloi Shibatta \& Benine, 2005 (MZUEL 7878), from the Couro de Boi Stream (Paraná State, 2305'41.4"'S 5059'49.5'W); M. parahybae Steindachner, 1880 (LBP 10741), from the rio Paraíba do Sul (Rio de Janeiro State, 22 $\left.04^{\prime} 07.8^{\prime \prime S} 41^{\circ} 54^{\prime} 36.2^{\prime \prime} \mathrm{W}\right)$ and Pseudopimelodus pulcher Boulenger, 1887 (MZUEL 6039), from rio Laranjinha (Paraná State, $23^{\circ} 24^{\prime} 52.98^{\prime \prime S} 50^{\circ} 27^{\prime} 8.55^{\prime \prime} \mathrm{W}$ ), using five individuals of each species.

Reactions were performed in $5 \mu \mathrm{L}$ reaction volume containing $1 \times$ GoTaq Master Mix (Promega), 10 ng of template DNA, $1 \%$ glycerol, $0.125 \mu \mathrm{M}$ forward labeled primer (FAM, HEX or NED, Applied Biosystems, CA), $0.125 \mu \mathrm{M}$ reverse primer, $0.0125 \mu \mathrm{M}$ forward primer. Amplifications were performed with an initial denaturation step at $94^{\circ} \mathrm{C}$ for $4 \mathrm{~min}$, followed by 35 cycles at $94^{\circ} \mathrm{C}$ for $40 \mathrm{~s}, 48^{\circ} \mathrm{C}, 54^{\circ} \mathrm{C}$ or $60^{\circ} \mathrm{C}$ (according to Table 1) for $1 \mathrm{~min}, 72^{\circ} \mathrm{C}$ for $1 \mathrm{~min}$, and a final extension at $72^{\circ} \mathrm{C}$ for $30 \mathrm{~min}$. The PCR products were submitted to electrophoresis on an automated sequencer (Applied Biosystems 3500 Genetic Analyzer) and the GeneScan $600 \mathrm{Liz}$ (Applied Biosystems) was used as the molecular weight standard.

The individuals were genotyped with the GeneMarker 1.85 software (SoftGenetics, State College, PA) followed by manual checking. Tests for Hardy-Weinberg Equilibrium (HWE) and the presence of linkage disequilibrium among the pairs of loci were calculated using GENEPOP 4.0.10 (Raymond \& Rousset, 1995; Rousset, 2008); $P$ values were subsequently adjusted applying the sequential Bonferroni correction (Rice, 1989). The software GenAlEx v.6.41 (Peakall \& Smouse, 2006) was used to estimate the observed $\left(H_{\mathrm{o}}\right)$ and expected $\left(H_{\mathrm{e}}\right)$ heterozygosities and the average number of alleles per locus. The paternity exclusion probability $(Q)$ (Weir, 1996), and the genetic identity probabilities (I) (Paetkau et al., 1995) were estimated using Identity 1.0 (Wagner \& Sefc, 1999). Estimates of the polymorphic information content (PIC) and potential null alleles were obtained through Cervus v.3.0 (Marshall et al., 1998) and Micro-Checker v.2.2.3 (Van Oosterhout et al., 2004) software, respectively. Default settings were used for all tests. 


\section{Results}

Of 96 clones sequenced, 25 contained microsatellite repeats but only 18 were suitable for primer design and PCR reactions. After testing the different amplification conditions, 13 loci were successfully amplified. From these, two were monomorphic and 11 were polymorphic (Table 1).

The eleven polymorphic loci produced a total of 108 different alleles, with high levels of variability, ranging from 2 to 20 , with an average of 8.3 alleles per locus. The observed and expected heterozygosity ranged from 0.125 to 0.958 and from 0.119 to 0.931 , respectively. After Bonferroni correction for multiple comparisons, no evidence of linkage disequilibrium between any pair of loci examined was observed. Only the locus Mcot09 showed significant deviation from Hardy-Weinberg equilibrium $(P<0.05)$. This locus showed the presence of null alleles, inferred from excess homozygous genotypes which could explain the observed deviation from HWE. Additionally, the locus Mcot08 revealed an excess of homozygotes and the possible presence of null alleles, but did not show any significant deviation from the HWE. It was also observed that the loci $M \cot 08$ and Mcot12 were the only ones showing significant values of endogamic coefficient $\left(F_{\text {IS }}\right)$ (Table 1).

\section{Discussion}

A high combined probability of paternity exclusion value (0.999) and a low combined probability of genetic identity value $\left(2.16 \times 10^{-6}\right)$ were obtained, showing that the set of loci described herein, exhibits good applicability for studies of parentage and population differentiation of $M$. cottoides.

The average PIC was 0.528 , ranging from 0.115 to 0.927 . According to Botstein et al. (1980), PIC values above 0.5 indicate highly informative markers; from 0.25 to 0.50 , moderately informative; and below 0.25 , slightly informative. Of the 13 loci obtained, eight proved to be highly informative (Mcot02, Mcot03, Mcot04, Mcot07, Mcot08, Mcot09, Mcot10 and Mcott12) with PIC values equal to or higher than 0.589 ; two were moderately informative (Mcot05 and Mcot11) presenting PIC values equal to or higher than 0.337 . Only one locus (Mcot13) was slightly informative, exhibiting a PIC value equal to 0.115 .

All 13 microsatellite primers developed for M. cottoides were successfully cross-amplified in two from four Pseudopimelodidae species (Table 2). Only two loci (Mcot04 and Mcot09) failed to amplify in P. pulcher and M. garavelloi, respectively. From the set of loci tested, Microglanis garavelloi and M. parahybae exhibited 10 polymorphic loci, while $M$. cibelae and $P$. pulcher showed, respectively, 11 and 12 polymorphic loci each.

Table 1. Description of 13 microsatellite loci (11 polymorphic and two monomorphic) isolated from the Neotropical fish Microglanis cottoides. Flanking primers, $\mathrm{T}_{\mathrm{a}}=$ optimal annealing temperatures, $k=$ number of alleles, allele size range (bp), $H_{\mathrm{o}}=$ observed heterozigosity, $H_{\mathrm{e}}=$ expected heterozygosity estimated from 30 individuals, $Q=$ paternity exclusion probability, $I=$ probability of genetic identity, $F_{\text {IS }}=$ endogamy coefficient, PIC = polymorphic information content, GenBank accession numbers. * Significant deviations from Hardy-Weinberg equilibrium $(\mathrm{P}<0.05)$. ** Significant value for the endogamy coefficient $\left(F_{I S}\right)$.

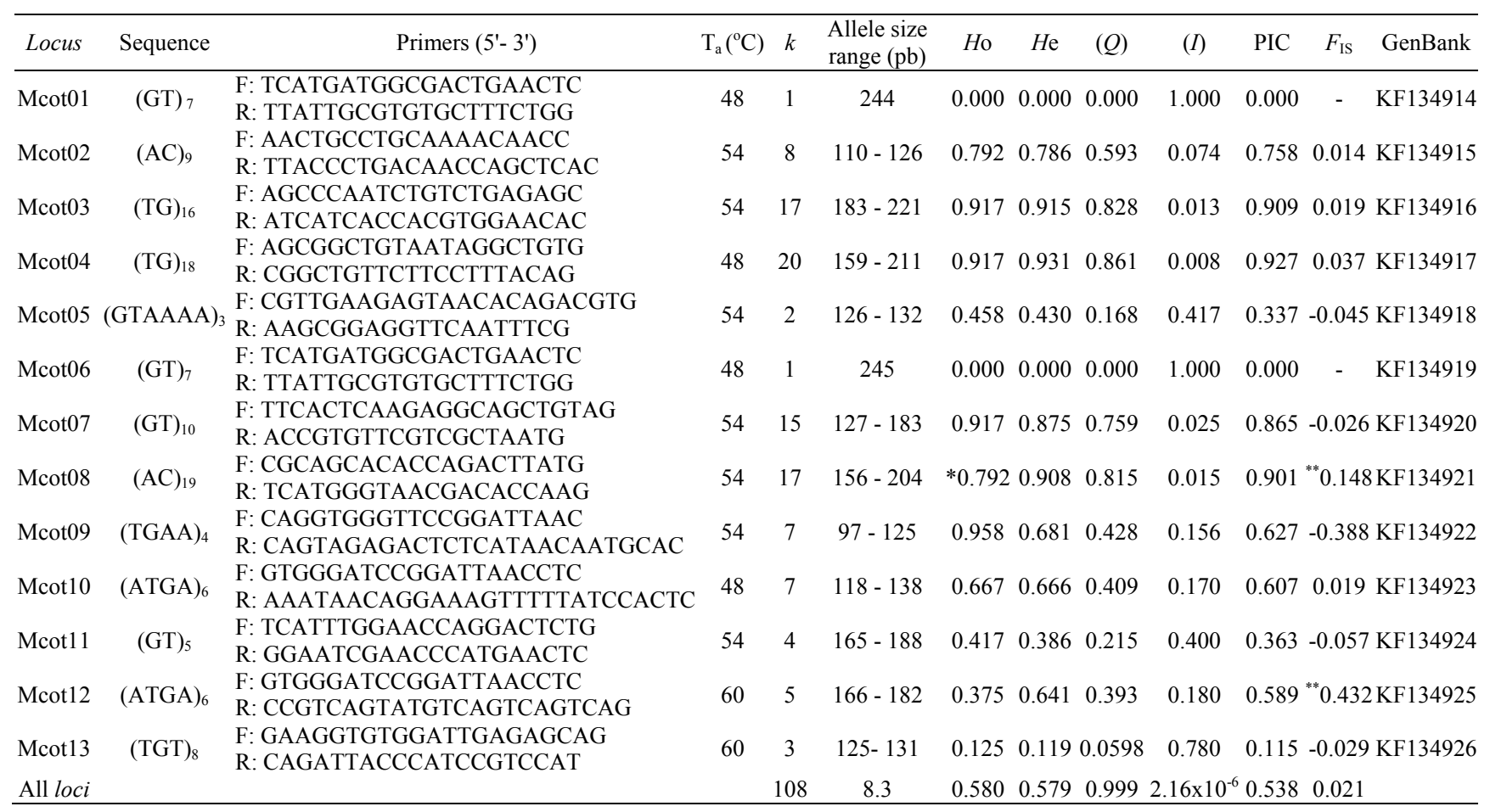


Table 2. Cross-amplification of 13 loci in four species of Pseudopimelodidae. Amplifications and polymorphisms were tested in five individuals of each species. - indicates no amplification. $k=$ the number of alleles per locus.

\begin{tabular}{|c|c|c|c|c|c|c|c|c|c|c|c|c|c|}
\hline \multirow[b]{3}{*}{ Species } & \multicolumn{13}{|c|}{ Primers } \\
\hline & Mcot01 & Mcot02 & Mcot03 & Mcot04 & Mcot05 & Mcot06 & Mcot07 & Mcot08 & Mcot09 & Mcot10 & Mcot11 & Mcot12 & Mcot13 \\
\hline & \multicolumn{13}{|c|}{ Allele size range (bp) and the number of alleles per locus observed $(k)$} \\
\hline \multirow[t]{2}{*}{ Microglanis cibelae } & 244-246 & $114-122$ & $104-218$ & $180-196$ & $114-132$ & $148-168$ & $244-246$ & $168-214$ & $113-125$ & $122-132$ & 165 & & 128 \\
\hline & & $k=$ & $k=$ & $k=$ & $k=$ & $k=$ & $k=$ & & $k=$ & & & & \\
\hline \multirow[t]{2}{*}{ Microglanis garavelloi } & 232 & $114-124$ & 195-197 & 181-191 & $112-132$ & $155-1$ & $232-256$ & $152-$ & - & 116 & 184 & $168-172$ & $126-129$ \\
\hline & $k=1$ & $k=3$ & $k=1$ & $k=$ & $k=$ & $k=$ & $k=2$ & $k=$ & - & $k=$ & $k=1$ & & $k=2$ \\
\hline \multirow[t]{2}{*}{ Microglanis parahybae } & 251 & $116-126$ & 202-208 & $207-221$ & 114-132 & $145-155$ & $244-252$ & $162-176$ & $114-124$ & $122-126$ & 184 & $170-178$ & 122 \\
\hline & & & $k=3$ & $k=4$ & $k=$ & $k=$ & $k=1$ & & $k=$ & & $k=$ & & \\
\hline \multirow[t]{2}{*}{ Pseudopimelodus pulcher } & $238-258$ & $100-134$ & $182-214$ & - & $110-156$ & $145-153$ & $245-247$ & $158-170$ & $115-197$ & $122-126$ & 186-192 & $170-174$ & $101-128$ \\
\hline & $k=4$ & $k=5$ & $k=6$ & - & $k=2$ & $k=4$ & $k=2$ & $k=5$ & $k=5$ & & $k=2$ & & $k=5$ \\
\hline
\end{tabular}

The successful cross-species amplification of microsatellite loci described herein can be attributed to the high conservatism of the flanking microsatellite regions, which is expected among close related species, as reported elsewhere (Barbará et al., 2007). Thus, the set of primers presented in the current study appear as promising tools for future population genetic studies involving these five species of Neotropical fish.

\section{Acknowledgments}

The authors are grateful to "Coordenação de Aperfeiçoamento de Pessoal de Nível Superior" (CAPES) for the scholarship granted to L. Souza-Shibatta, and Fundação Araucária for their financial support to this research (Programa Universal 05/2011, protocol 22.633); Lúcia Giuliano Caetano (Universidade Estadual de Londrina) for donating samples of $M$. cottoides; Claudete F. Ruas, for helping build the library; and IBAMA/SISBIO, for providing permission to collect fish (License $\mathrm{n}^{\circ}$ 12120-1). The authors also thank to the anonymous referees, who contributed with valuable comments and suggestions.

\section{Literature Cited}

Alcaraz, H. S. V., W. J. Graça \& A. O. Shibatta. 2008. Microglanis carlae, a new species of bumblebee catfish (Siluriformes: Pseudopimelodidae) from the río Paraguay basin in Paraguay. Neotropical Ichthyology, 6: 425-432.

Almeida, F. S., M. H. Pelegrinelli \& L. M. K. Sodré. 2001. RAPD and isoenzyme analysis of genetic variability in three allied species of catfish (Siluriformes: Pimelodidae) from the Tibagi River, Brazil. Journal of Zoology, 253: 113-120.

Avise, J. C. 2001. Phylogeography: The History and Formation of Species. Harvard University Press, New Haven, Connecticut.

Avise, J. C. 2009. Retrospect and prospect. Journal of Biogeography, 36: 3-15.

Barbará, T., C. Palma-Silva, G. M. Paggi, F. Bered, M. F. Fay \& Lexer, C. 2007. Cross-species transfer of nuclear microsatellite markers: potential and limitations. Molecular Ecology, 16: 3759-3767.

Bertaco, V. A. \& A. R. Cardoso. 2005. A new species of Microglanis (Siluriformes: Pseudopimelodidae) from the rio Uruguay drainage, Brazil. Neotropical Ichthyology, 3: 61-67.

Billotte, N., P. J. Lagoda, A. M. Risterucci \& F. C. Baurens. 1999. Microsatellite enriched libraries: applied methodology for the development of SSR markers in tropical crops. Fruits, 54: 277-288.

Bizerril, C. R. S. F. 1994. Análise taxonômica e biogeográfica da ictiofauna de água doce do leste brasileiro. Acta Biológica Leopoldinense, 18: 51-80.

Bizerril, C. R. S. F. 1995. Análise da distribuição espacial da ictiofauna de uma bacia hidrográfica do leste brasileiro. Arquivos de Biologia e Tecnologia, 38: 477-499.

Botstein, D. R. L. White, M. Skolnick \& R. W. Davis. 1980. Construction of a Genetic Linkage Map in Man Using Restriction Fragment Length Polymorphisms. American Journal of Human Genetics, 32: 314-331.

Esguícero, A. L. H. \& M. S. Arcifa. 2010. Which is the best environment for the development of the early life stages of fish during the dry season? Acta Limnologica Brasiliensia, 22: 267-275.

Hall, T. A. 1999. BioEdit: a user-friendly biological sequence alignment editor and analysis program for Windows 95/98/NT. Nucleic Acids Symposium Series, 41: 95-98.

Hardy, M. E. J., M. Grady \& E. J. Routman. 2002. Intraspecific phylogeography of the slender madtom: the complex evolutionary history of the Central Highlands of United States. Molecular Ecology, 11: 2393-2403.

Lundberg, J. G., A. H. Bornbusch \& F. Mago-Leccia. 1991. Gladioglanis conquistador n. sp. from Ecuador with diagnoses of the Subfamilies Rhamdiinae Bleeker and Pseudopimelodidae n. subf. (Siluriformes: Pimelodidae). Copeia, 1991: 190-209.

Malabarba, L. R. \& J. K. F. Mahler-Jr. 1998. Review of the genus Microglanis in the rio Uruguay and coastal drainages of southern Brazil (Ostariophysi: Pimelodidae). Ichthyological Exploration of Freshwaters, 9: 243-254.

Marshall, T. C., J. Slate, L. E. B. Kruuk \& J. M. Pemberton. 1998. Statistical confidence for likelihood-based paternity inference in natural populations. Molecular Ecology, 7: 639-655.

Mori, H. \& O. A. Shibatta. 2006. A new species of Microglanis Eigenmann 1912 (Siluriformes, Pseudopimelodidae) from rio São Francisco basin, Brazil. Zootaxa, 1302: 31-42.

O’Connell, M. \& J. M. Wright. 1997. Microsatellite DNA in fishes. Reviews in Fish Biology and Fisheries, 7: 331-363.

Ottoni, F. P., J. L. O. Mattos \& M. A. Barbosa. 2010. Description of a new species of Microglanis from the rio Barra Seca basin, southeastern Brazil (Teleostei: Siluriformes: Pseudopmelodidae). Vertebrate Zoology, 60: 187-192.

Paetkau, D., W. Calvert, I. Stirling \& C. Strobeck. 1995. Microsatellite analysis of population structure in Canadian polar bears. Molecular Ecology, 4: 347-354. 
Peakall, R. \& P. E. Smouse. 2006. GENEALEX 6: genetic analysis in Excel. Population genetic software for teaching and research. Molecular Ecology Notes, 6: 288-295.

Raymond, M. \& F. Rousset. 1995. GENEPOP (version 1.2): population genetics software for exact tests and ecumenicism. Journal of Heredity, 86: 248-249.

Rice, W. R. 1989. Analyzing tables of statistical tests. Evolution, 43: 223-225.

Rousset, F. 2008. GENEPOP'007: a complete re-implementation the GENEPOP software for Windows and Linux. Molecular Ecology Resources, 8: 103-106.

Rozen, S. \& H. J. Skaletsky. 2000. Primer 3 on the www for general users and for biologist programmers. In: Bioinformatics Methods and Protocols: Methods in Molecular Biology. Pp. 365-386. In: Krawetz S. \& S. Misener S (Eds.). Humana Press, Totowa.

Ruiz, W. B. G. \& O. A. Shibatta. 2010. A new species of Microglanis (Siluriformes, Pseudopimelodidae) from lower Rio Tocantins basin, Pará, Brazil, with description of superficial neuromasts and pores of lateral line system. Zootaxa, 2632: 53-66.

Ruiz, W. B. G. \& O. A. Shibatta. 2011. Two new species of Microglanis (Siluriformes, Pseudopimelodidae) from the uppermiddle Araguaia basin, Central Brazil. Neotropical Ichthyology, 9: 697-707.

Sarmento-Soares, L. M., R. F. Martins-Pinheiro, C.C. Chamon \& A.T. Aranda. 2006. Microglanis pataxo, a new catfish from southern Bahia coastal rivers, northeastern Brazil (Siluriformes: Pseudopimelodidae). Neotropical Ichthyology, 4: 157-166.

Schuelke, M. 2000. An economic method for the fluorescent labeling of PCR fragments. Nature Biotechnologies, 18: 223-234.

Shibatta, O. A. 2003a. Family Pseudopimelodidae. Pp. 401-405. In: Reis, R. E., S. O. Kullander \& C. J. Ferraris (Eds.). Checklist of the Freshwater Fishes of South and Central America. Porto Alegre, Edipucrs.
Shibatta, O. A. 2003b. Phylogeny and classification of 'Pimelodidae'. Pp. 385-400. In: Arratia, G., B. G. Kapoor, M. Chardon \& R. Diogo (Eds.). Catfishes. Science Publishers, Enfield.

Shibatta, A. O. \& R. C. Benine. 2005. A new species of Microglanis (Siluriformes: Pseudopimelodidae) from upper rio Paraná basin, Brazil. Neotropical Ichthyology, 3: 579-585.

Shibatta, O. A. 2007. Família Pseudopimelodidae. Pp. 103-104. In: Buckup, P. A., N. A. Menezes \& M. S. Ghazzi (Eds.). Catálogo das Espécies de Peixes de Água Doce do Brasil. Rio de Janeiro, Universidade Federal do Rio de Janeiro.

Vallone, M. V. \& J. M. Butler. 2004. AutoDimer: a screening tool for primer-dimer and hairpin structures. BioTechniques, 37: 226-231.

Van Oosterhout, C., W. F. Hutchinson, D. P. M. Wills \& P. F. Shipley. 2004. Micro-Checker: software for identifying and correcting genotyping errors in microsatellite data. Molecular Ecology Notes, 4: 535-538.

Wagner, H. W. \& K. M. Sefc. 1999. IDENTITY 1.0. Centre for Applied Genetics, University of Agricultural Sciences, Vienna. Available from http://www.boku.ac.at/zag/forsch/identity.htm. (18 March 2013)

Weir, B. S. 1996. Genetic Data Analysis II. Sunderland, MA: Sinauer Associates, Inc.

Zane, L., L. Bargelloni \& T. Patarnello. 2002. Strategies for microsatellite isolation: A review. Molecular Ecology, 11: 1-16.

Submitted July 3, 2013

Accepted August 26, 2013 by Alexandre Hilsdorf Published September 30, 2013 